\title{
Costs of Establishing Organic Northern Highbush Blueberry: Impacts of Planting Method, Fertilization, and Mulch Type
}

\author{
James W. Julian
}

Department of Agriculture and Resource Economics, Oregon State University, 213 Ballard Extension Hall, Corvallis, OR 97331

Bernadine C. Strik ${ }^{\mathbf{1}, \mathbf{3}}$ and Handell O. Larco ${ }^{2}$

Department of Horticulture, Oregon State University, 4017 ALS, Corvallis, OR 97331

\section{David R. Bryla}

U.S. Department of Agriculture, Agricultural Research Service, Horticultural Crops Research Unit, 3420 NW Orchard Avenue, Corvallis, OR 97330

\section{Dan M. Sullivan \\ Department of Crop and Soil Science, Oregon State University, 3045 ALS, Corvallis, OR 97331}

Additional index words. Vaccinium corymbosum, sawdust, compost, weed mat, landscape fabric, fish emulsion, feather meal, economics, cost of production

\begin{abstract}
A systems trial was established to evaluate factorial management practices for organic production of northern highbush blueberry (Vaccinium corymbosum L.). The practices included: flat and raised planting beds; feather meal and fish emulsion fertilizer applied at 29 and $57 \mathrm{~kg} \cdot \mathrm{ha}^{-1}$ of nitrogen (N); sawdust mulch, compost topped with sawdust mulch (compost + sawdust), or weed mat; and two cultivars, Duke and Liberty. The planting was established in Oct. 2006 and was certified organic in 2008. Weeds were managed by hand-hoeing or pulling in sawdust and weed mat-mulched plots and a combination of hand-pulling, propane-flaming, and post-emergent, targeted applications of acetic acid or lemon grass oil to any weeds present in the compost + sawdust plots depending on year. Data were recorded on input costs and returns in Year 0 (establishment year) through Year 3. Plants were harvested beginning the second year after planting. Planting costs were $\$ 741 /$ ha higher on raised beds than on the flat, but the higher costs were more than offset by an average of $63 \%$ greater yields that improved net returns by as much as $\$ 2861 / \mathrm{ha}$. Cumulative net returns after 3 years were negative and ranged from $-\$ 32,967$ to $-\$ 50,352 /$ ha when grown on raised beds and from $-\$ 34,320$ to $-\$ 52,848 /$ ha when grown on flat beds, depending on cultivar, mulch, and fertilizer rate and source. The greatest yields were obtained in plants fertilized with the low rate of fish emulsion or the high rate of feather meal, but fertilizing with fish emulsion by hand cost (materials and labor) as much as $\$ 5066 /$ ha more than feather meal. Higher costs of establishment and pruning for 'Liberty' compared with 'Duke' were offset by higher net returns in all treatment combinations, except feather meal fertilizer with either weed mat or compost + sawdust mulch. Mulch type affected establishment costs, weed presence, and weed management costs, which included product and labor costs for application of herbicides (acetic acid and lemon grass oil) as well as labor for hand-weeding as needed, depending on the treatment. The highest yielding treatment combinations (growing on raised beds mulched with compost + sawdust and fertilized with fish emulsion) improved cumulative net returns as much as $\$ 19,333 /$ ha over 3 years.
\end{abstract}

Northern highbush blueberries are longlived perennial plants, requiring 7 years or more to reach full production. The cash costs to establish new plantings, through Year 6, can surpass $\$ 30,165 /$ ha with net cumulative returns of $-\$ 9,995 /$ ha (a loss) for conventional blueberry in Oregon (Julian et al., 2011a). In contrast, the cash costs required to establish a "typical" organic blueberry field in Oregon were higher $(\$ 32,520 / \mathrm{ha})$ but cumulative returns through Year 6 were positive $(\$ 6,930 /$ ha; Julian et al., 2011b). In plantings yielding $18 \mathrm{t} \cdot \mathrm{ha}^{-1}$, the breakeven price (to cover total cash costs) was estimated at $\$ 3.08$ and $\$ 10 / \mathrm{kg}$ for organic blueberries produced in Oregon (Julian et al., 2011b) and southern California (Takele et al., 2008), respectively. Net cash costs of production are greatly impacted by production system, yield, and price obtained for fruit. Organic production systems for blueberry vary among growers and regions. Although estimated net returns are greater for organic production than conventional (Julian et al., 2011a, 2011b), little is known about the impact of various production systems on the performance and returns of organically grown northern highbush blueberry.

Blueberry plants have shallow roots and grow best on well-drained, high organic matter, acid soils (Eck, 1988). Planting on raised beds is a common production system in blueberry fields (Strik, 2007) to improve drainage and help protect plants from standing water (Scherm and Krewer, 2008). In contrast, planting on flat ground is thought to increase soil moisture and reduce soil temperature during the fruiting season, which is beneficial to root growth of southern highbush blueberry (hybrids of $V$. corymbosum L. and $V$. darrowi Camp.; Spiers, 1995) and may be easier to manage for weed control.

In general, the best growth and yield of blueberry have been achieved with $\mathrm{N}$ fertilization rates of 25 to $100 \mathrm{~kg} \cdot \mathrm{ha}^{-1}$ (Bañados et al., 2012; Chandler and Mason, 1942; Eck, 1988; Griggs and Rollins, 1947; Hanson, 2006; Hart et al., 2006) at an estimated cost of $\$ 1$ to $\$ 2 / \mathrm{kg}$ for synthetic $\mathrm{N}$ fertilizer. Organic blueberry farmers commonly use Organic Materials Review Institute (OMRI)-approved fish emulsion as a direct liquid application or injected through the drip irrigation system and granular feather meal as N fertilizer sources. Supplying $\mathrm{N}$ from feather meal or fish fertilizers has an estimated product cost to growers of $\$ 10$ to $\$ 25 / \mathrm{kg} \mathrm{N}$ applied.

Application of surface mulch has been shown to improve production in blueberry through improved weed control, soil moisture, and plant growth (Burkhard et al., 2009; Clark, 1991; Clark and Moore, 1991; Krewer et al., 2009; Lareau, 1989; Moore, 1979; White, 2006). Historically, Douglas fir (Pseudotsuga menziesii M.) sawdust was readily available and commonly used in conventional and organic blueberry production systems in the northwestern United States. However, sawdust has become increasingly expensive and has a high carbon (C) to $\mathrm{N}$ ratio making plant fertility more difficult and expensive to manage with organic fertilizer products (White, 2006). The use of compost as a mulch in blueberry may have advantages over sawdust. Compost has a lower $\mathrm{C}$ to $\mathrm{N}$ ratio and releases $3 \%$ to $10 \%$ of its total $\mathrm{N}$ during decomposition for several years after application (Gale et al., 2006; Sikora and Szmidt, 2001).

Weed mat or landscape fabric, an inert mulch (Granatstein and Mullinix, 2008) approved for use as a weed barrier by the USDA Organic National Program (USDA-AMS-NOP, 2011), is an alternative to sawdust mulch. Weed mat is used widely in tree fruit orchards, mainly because of its effectiveness for weed control, although weeds appear in the planting hole and removal by hand may be required (Runham et al., 2000). Sciarappa et al. (2008) reported almost complete control of weeds when using weed mat plus a mulch of coffee grinds around the planting area in organic blueberry in New Jersey. However, concerns have been expressed 
about possible negative impacts of increasing soil temperature under weed mat on plant growth (Neilsen et al., 2003; Williamson et al., 2006).

Weed management in blueberry is critical for economic production because weed presence decreases yield (Burkhard et al., 2009; Krewer et al., 2009; Pritts and Hancock, 1992; Strik et al., 1993). Pre-emergent and contact herbicides are commonly used in conventional production systems, whereas chemical options are limited to OMRI-approved products containing acetic acid or lemon grass oil in organic systems. Acetic acid (vinegar) at a concentration of $9 \%$ to $20 \%$ has been effective at controlling some weeds (Fausey, 2003; Young, 2004). Organic growers also use mulch and hand removal to control weeds. Propane flaming may be an option to control smaller weeds but may damage the crop plant (Granatstein and Mullinix, 2008).

The objectives of this study were to evaluate the effects of flat and raised planting beds, three different mulch types, including sawdust, compost plus sawdust, and weed mat, and the use of feather meal and fish emulsion fertilizer applied at two rates on initial establishment costs and returns for organic production of 'Duke' and 'Liberty' blueberry. 'Duke' is an early-season cultivar that ripens in late June to early July in Oregon, whereas 'Liberty' is a mid- to late-season cultivar that ripens in late July to early August.

\section{Materials and Methods}

Study site. A 0.43-ha field of northern highbush blueberry (Vaccinium corymbosum L.) was established in Oct. 2006 on a site in transition to organic production at the North Willamette Research and Extension Center (lat. $45^{\circ} 16^{\prime} 47.55^{\prime \prime} \mathrm{N}$, long. $122^{\circ} 45^{\prime} 21.90^{\prime \prime} \mathrm{W}$ ), Aurora, OR. Winter wheat (Triticum sp.) was planted in the field for at least 10 years before the study. Soil at the site is a Willamette silt loam (fine-silty mixed superactive mesic Pachic Ultic Argixeroll). Organic matter content in the soil averaged $3.7 \%$ at planting, and soil $\mathrm{pH}$ averaged 4.9 . The planting was certi-

\footnotetext{
Received for publication 6 Apr. 2012. Accepted for publication 10 May 2012.

We would like to recognize the financial support provided by the Oregon Blueberry Commission, the Northwest Center for Small Fruits Research, The Washington Blueberry Commission, and the NIFA-OREI program. We appreciate the valuable assistance of Emily Vollmer and Gil Buller at Oregon State University.

Mention of a trademark, proprietary product, or vendor does not constitute a guarantee or warranty of the product by Oregon State University or the U.S. Dept. of Agriculture and does not imply its approval to the exclusion of other products or vendors that also may be suitable.

${ }^{1}$ Professor and Extension Berry Crops Specialist. ${ }^{2}$ Former MS graduate student. Present address: Driscoll Strawberry Associates, Inc., 1750 San Juan Rd. Aromas, CA 95004.

${ }^{3}$ To whom reprint requests should be addressed; e-mailstrikb@hort.oregonstate.edu.
}

fied organic by Oregon Tilth (OTCO, Salem, OR) in May 2008. Additional information on site preparation, planting, weed control, and irrigation is provided in Larco (2010).

Experimental design. Forty-eight treatments were arranged in a split-split plot design and included two bed types (flat and raised) as main plots, four fertilizer treatments (feather meal and fish emulsion applied at rates of 29 and $57 \mathrm{~kg} \cdot \mathrm{ha}^{-1}$ of N) as subplots, and a combination of three mulch treatments (sawdust, compost + sawdust, and weed mat) and two cultivars (Duke and Liberty) as sub-subplots. There were five replicates. The five main plots consisted of two rows of plants each (one flat and one raised), and each sub-subplot consisted of six plants. Rows were spaced $3.0 \mathrm{~m}$ apart, and plants were spaced $0.76 \mathrm{~m}$ apart within sub-subplots (4385 plants/ha) and $1.5 \mathrm{~m}$ apart between sub-subplots. A guard row was also planted on each side of the field.

'Duke' and 'Liberty' plants were obtained from a local nursery as 2-year-old container stock and transplanted on 9 Oct. 2006. The field was ripped and rototilled before planting. Raised beds $(0.3 \mathrm{~m}$ high and $1.5 \mathrm{~m}$ wide at the base) were formed using a bed shaper. Douglas fir sawdust (Pseudotsuga menziesii M.; Decorative Bark, Lyons, OR) and yard debris compost (Rexius, Inc., Eugene, OR) mulch were applied on 12 Oct. 2006. Beds mulched with sawdust were covered $9 \mathrm{~cm}$ deep $\left(360 \mathrm{~m}^{3} \cdot \mathrm{ha}^{-1}\right)$ whereas those mulched with compost + sawdust were covered with $4 \mathrm{~cm}$ of compost $\left(152 \mathrm{~m}^{3} \cdot \mathrm{ha}^{-1}\right)$ followed by $5 \mathrm{~cm}$ of sawdust $\left(200 \mathrm{~m}^{3} \cdot \mathrm{ha}^{-1}\right)$. We selected yard debris compost for this study because it had relatively low salt (electrical conductivity) and we could apply high rates of stable organic matter without danger of excess plant-available $\mathrm{N}$ application (Larco, 2010). The slow-release $\mathrm{N}$ provided by the yard debris compost was estimated at roughly $25 \mathrm{~kg}$ of $\mathrm{N} \cdot \mathrm{ha}^{-1} /$ year ( $3 \%$ of total compost-N applied) based on our experience with similar composts applied before planting in grass (Sullivan et al., 2003) and sweet corn (Gale et al., 2006). The compost was topped with sawdust with the goal of creating a barrier to weed establishment. The mulches were spread mechanically in 0.75-m-wide strips on each side of the plant rows. Black weed mat (Baycor; TenCate Protective Fabrics, Union City, GA) made from woven polypropylene was installed on $1 \mathrm{Feb}$. 2007. The weed mat was $1.5 \mathrm{~m}$ wide and centered over the planting beds before securing it in place with landscape staples. A $20-\mathrm{cm}-$ diameter hole was cut in the weed mat for each plant and covered with $5 \mathrm{~cm}$ of sawdust mulch $\left(1.4 \mathrm{~m}^{3} \cdot \mathrm{ha}^{-1}\right)$ after planting. Certified organic grass seed (Festulolium braunii K. Richt.) was planted between rows at a rate of $28 \mathrm{~kg} \cdot \mathrm{ha}^{-1}$ on 14 Oct. 2006.

Feather meal (Nature Safe, Cold Spring, $\mathrm{KY} ; 13 \mathrm{~N}-0 \mathrm{P}-0 \mathrm{~K})$ was applied around the base of the plants in two equal applications on 3 Apr. and 16 May in 2007, 4 Mar. and 22 Apr. in 2008, and 4 Mar. and 15 Apr. in 2009. Fish emulsion (Fish Agra; Northeast Organics, Manchester-by-the-Sea, MA; 4N-0.4P-0.8K) was also applied around the base of the plants but every 2 weeks from 16 Apr. to 9 July in 2007,15 Apr. to 8 July in 2008 , and 8 Apr. to 1 July in 2009. To reduce risk of salt damage to the plants, fish emulsion was diluted with 10 parts water before each application. Plants fertilized with feather meal were deficient in $\mathrm{N}$ during the first summer after planting (Larco, 2010) and, therefore, were fertilized with an additional $4 \mathrm{~kg} \cdot \mathrm{ha}^{-1}$ of $\mathrm{N}$ as fish emulsion on 28 June and 5 July 2007. The plants recovered quickly and did not require additional fertilization with fish emulsion in subsequent years.

Field management. Plants were irrigated using a single line of polyethylene drip tubing (Netafim, Fresno, CA). The tubing had $2 \mathrm{~L} \cdot \mathrm{h}^{-1}$ pressure-compensating, inline emitters spaced every $0.3 \mathrm{~m}$. Lines were located along the row near the base of plants and either placed beneath the weed mat or buried under the organic mulches. Irrigation was controlled by electric solenoid valves and an automatic timer set weekly and scheduled based on changes in soil water content [see Larco (2010) for details]. A second line of drip (located near the base of the plants, but on the other side of the row of the first line) was also installed in weed mat plots to allow for additional irrigation to compensate for increased water use associated with higher temperatures in the treatment (Neilsen et al., 2003; Williamson et al., 2006).

Weeds were removed by hand from plots mulched with sawdust and weed mat and by a combination of $20 \%$ acetic acid (vinegar) applications, propane-flaming, and handweeding in plots mulched with compost + sawdust. Vinegar applications were done after 1000 HR on days with no rain and light wind in 2007 to 2008 (Webber et al., 2005). A handheld propane flamer was constructed with a 0.20 -m-diameter head and an 860,000 to $1,505,000-\mathrm{kg} \cdot \mathrm{m}^{-1}$ small gas heater attached to a rod to facilitate spot burning in 2008 . Lemon grass oil (50\% a.i.; Green Match $\mathrm{EX}^{\circledR}$; Marrone Bioinnovations, Davis, CA) was used as a directed post-emergence spray to weeds in compost + sawdust plots in 2009 . Hand-pulling or herbicide treatments, depending on mulch treatment, were done only when weed coverage was more than $20 \%$.

Plants were pruned in Oct. 2006 (Year 1) and Jan. 2008 (Year 2) and 2009 (Year 3). To maximize vegetative growth during establishment, all fruit buds were removed from the plants in the first year after planting (Oct. 2006; Strik and Buller, 2005). The next year, pruning was adjusted to plant size with proportionally more fruit buds left on larger plants and few or none left on the smallest plants.

'Duke' was harvested from 3 July to 23 July and 'Liberty' was harvested from 23 July to 13 Aug. in 2008. In 2009, fruit harvest was from 2 June to 17 July and 22 July to 22 Aug. for 'Duke' and 'Liberty', respectively. Ripe fruit was picked weekly by hand and weighed to determine the total yield per plot. Fruit were sold to a fresh-market shipper and the price was recorded. 
Statistical analysis. Analysis of all treatment effects on yield and pruning time was done as a complete factorial for a split-split plot design using the PROC MIXED procedure in SAS software package Version 8

Table 1. Cash costs, before planting, common to all production system treatments, 2006.

\begin{tabular}{|c|c|}
\hline Operation & Cost $(\$ / \mathrm{ha})$ \\
\hline \multicolumn{2}{|l|}{ Soil preparation } \\
\hline $\begin{array}{l}\text { Plow and culti-pak, } \\
\text { custom operation }\end{array}$ & 247 \\
\hline \multicolumn{2}{|l|}{ Pre-plant cover crop } \\
\hline Buckwheat seed & 247 \\
\hline $\begin{array}{l}\text { Seed bed preparation } \\
\text { and planting, custom }\end{array}$ & 247 \\
\hline \multicolumn{2}{|l|}{ Soil preparation for planting } \\
\hline Soil testing & 17 \\
\hline $\begin{array}{l}\text { Disc and culti-pak, } \\
\text { custom }\end{array}$ & 247 \\
\hline $\begin{array}{l}\text { Power spading and } \\
\text { sub-soiling }\end{array}$ & 494 \\
\hline $\begin{array}{l}\text { Deep tillage and } \\
\text { rototilling, custom }\end{array}$ & 247 \\
\hline $\begin{array}{l}\text { Irrigation-hand pipe } \\
\text { (to wet soil before hilling) }\end{array}$ & 124 \\
\hline \multicolumn{2}{|l|}{ Between rowcover crop (grass) } \\
\hline $\begin{array}{l}\text { Organic certified seed } \\
\text { (Festulolium braunii) }\end{array}$ & 334 \\
\hline $\begin{array}{l}\text { Seed bed preparation and } \\
\text { planting, custom }\end{array}$ & 247 \\
\hline
\end{tabular}

(SAS Institute, Cary, NC). Contrasts were used to compare the effect of fertilizer source and rate on net returns.

Economic budget analysis. Input costs (labor, equipment, and product) were recorded from establishment (Year 0; 2006) through Year 3 (2009) for all activities required to maintain the treatment plots and were extrapolated to a per-hectare cost. Cash cost and return budgets were constructed for each treatment to compare net returns from each production system as well as to evaluate each treatment independently. Cost assumptions used in the assessment of the various treatments were as follows: 1) blueberry plants cost $\$ 3.15$ each for 'Duke' and $\$ 3.45$ each for 'Liberty'; 2) pre-plant land preparations (plowing, disking, etc.) were contracted using a custom farming provider at $\$ 30 / \mathrm{h} ; 3$ ) weed mat cost \$2965/ha and has a life expectancy of 5 years; 4) sawdust mulch cost $\$ 7.85 / \mathrm{m}^{3}$, and compost mulch cost $\$ 11.35 / \mathrm{m}^{3}$. Sawdust and compost mulches were customapplied separately. Application of sawdust alone cost $\$ 1050 /$ ha, whereas application of both sawdust and compost cost $\$ 1482 /$ ha; 5) the drip irrigation system cost $\$ 5683 /$ ha and has a life expectancy of 10 years. Repair and maintenance of the system cost $1 \%$ of the purchase price per year; 6) the trellis system cost $\$ 4200 /$ ha and was amortized over a 30 year life. Repair and maintenance of the system cost $1 \%$ of the purchase price per

Table 2. Effects of organic production systems on economic returns (\$/ha) of 'Duke' and 'Liberty' blueberry in the second (2008) and third (2009) growing seasons $(n=5)$.

\begin{tabular}{|c|c|c|c|c|c|c|c|c|}
\hline \multirow[b]{4}{*}{ Fertilizer/mulch } & \multicolumn{8}{|c|}{ Returns (\$/ha) } \\
\hline & \multicolumn{4}{|c|}{2008 (Year 2) } & \multicolumn{4}{|c|}{2009 (Year 3) } \\
\hline & \multicolumn{2}{|c|}{ Flat bed } & \multicolumn{2}{|c|}{ Raised bed } & \multicolumn{2}{|c|}{ Flat bed } & \multicolumn{2}{|c|}{ Raised bed } \\
\hline & Duke & $\overline{\text { Liberty }}$ & $\overline{\text { Duke }}$ & $\overline{\text { Liberty }}$ & Duke & $\overline{\text { Liberty }}$ & Duke & Liberty \\
\hline \multirow{2}{*}{\multicolumn{9}{|c|}{$\begin{array}{l}\text { Feather meal } \\
29 \mathrm{~kg} \cdot \mathrm{ha}^{-1} \mathrm{~N}\end{array}$}} \\
\hline & & & & & & & & \\
\hline Sawdust & 1,177 & 3,396 & 1,588 & 4,620 & 16,434 & 14,018 & 20,422 & 19,214 \\
\hline Compost + sawdust & 1,904 & 5,128 & 2,780 & 5,981 & 21,147 & 16,555 & 20,180 & 22,235 \\
\hline Weed mat & 2,876 & 5,271 & 3,786 & 6,166 & 19,939 & 19,939 & 22,476 & 25,497 \\
\hline \multicolumn{9}{|l|}{$57 \mathrm{~kg} \cdot \mathrm{ha}^{-1} \mathrm{~N}$} \\
\hline Sawdust & 868 & 2,516 & 2,913 & 5,914 & 13,655 & 15,226 & 22,356 & 25,618 \\
\hline $\mathrm{t}+$ sawdust & 1,705 & 4,641 & 4,010 & 7,655 & 21,389 & 16,555 & 30,452 & 25,256 \\
\hline Weed mat & 3,518 & 6,176 & 4,980 & 7,077 & 23,443 & 23,081 & 30,452 & 23,201 \\
\hline \multicolumn{9}{|l|}{ Fish emulsion } \\
\hline $29 \mathrm{~kg} \cdot \mathrm{ha}^{-1} \mathrm{~N}$ & & & & & & & & \\
\hline Sawdust & 5,172 & 5,453 & 5,747 & 6,154 & 18,174 & 18,174 & 20,543 & 24,289 \\
\hline Comp & 5,046 & 6,056 & 6,953 & 8,004 & 20,809 & 18,029 & 21,389 & 27,600 \\
\hline Weed mat & 6,406 & 6,490 & 7,794 & 7,654 & 21,171 & 21,776 & 25,280 & 27,818 \\
\hline \multicolumn{9}{|l|}{$57 \mathrm{~kg} \cdot \mathrm{ha}^{-1} \mathrm{~N}$} \\
\hline Sawdust & 3,603 & 3,438 & 4,846 & 5,859 & 11,117 & 12,809 & 20,180 & 21,026 \\
\hline Compost + sawdust & 3,802 & 4,494 & 5,698 & 6,602 & 14,501 & 17,401 & 19,697 & 22,114 \\
\hline Weed mat & 3,084 & 5,128 & 5,334 & 6,151 & 12,930 & 20,543 & 12,809 & 21,026 \\
\hline
\end{tabular}

Significance $^{\mathrm{z}}$

(A) Raised vs. flat

(B) Fertilizer

(C) Mulch

(D) Cultivar

$\mathrm{A} \times \mathrm{C}$

$\mathrm{B} \times \mathrm{D}$

$\mathrm{B} \times \mathrm{C} \times \mathrm{D}$

Contrasts

Feather vs. fish

Low vs. high rate

$\begin{array}{cc}* & * * * \\ * * * & * * * \\ * * * & * * * \\ * * * & \mathrm{NS} \\ \mathrm{NS} & * \\ * * * & * * * \\ \mathrm{NS} & * \\ * * * & * \\ \mathrm{NS} & \mathrm{NS}\end{array}$

${ }^{\text {z} \text { Significance based on analysis of variance by year. Only significant interactions shown: Ns, }{ }^{*}, * *, * * * \text { non- }}$ significant or significant at $P \leq 0.05,0.01$, or 0.001 , respectively.

$\mathrm{N}=$ nitrogen.

year; 7) expenses to reduce bird depredation were \$124/ha per year; 8) seven bee hives/ha were rented during production years at a cost of $\$ 50$ each; 9) all labor was valued at $\$ 15 / \mathrm{h}$, which included worker's compensation, unemployment insurance, and other labor overhead expenses; and 10) the tractor and sprayer used to apply acetic acid cost $\$ 17 / \mathrm{h}$, inclusive of all associated variable and fixed costs. The wage rate of the tractor operator was $\$ 15 / \mathrm{h}$.

\section{Results and Discussion}

Development of the planting from the first through the third growing season is shown in Figures 1 through 3 . Pre-plant costs (Table 1) were consistent with those calculated for commercial organic blueberry production (Julian et al., 2011b). Yield was significantly affected by bed type, fertilizer, and mulch in 2008 and 2009; cultivar in 2008; and by bed type $\times$ mulch (2009), fertilizer $\times$ cultivar (2008-2009), and fertilizer $\times$ mulch $\times$ cultivar (2009) (Table 2).

Bed type. Raised beds cost $\$ 741 /$ ha more than flat beds (Table 3) to establish but increased gross returns by an average of $63 \%$ in 2008 to 2009 (Table 2) and cumulative net returns by an average of $\$ 2861 /$ ha (Tables 4 and 5). In 2009, returns were similar across mulch types on raised beds but were greater for compost + sawdust and weed mat mulches when grown on flat ground

Table 3. Planting operation cash costs as affected by production system treatments, 2006 .

\begin{tabular}{|c|c|}
\hline Operation & Cost $(\$ / h a)$ \\
\hline \multicolumn{2}{|l|}{ Forming raised beds } \\
\hline $\begin{array}{l}\text { Hilling (custom } \\
\text { equipment and labor) }\end{array}$ & 741 \\
\hline \multicolumn{2}{|l|}{ Blueberry plants } \\
\hline 'Liberty' (at \$3.45 each) & 15,128 \\
\hline 'Duke’ (at \$3.15 each) & 13,813 \\
\hline \multicolumn{2}{|l|}{ Mulch treatments } \\
\hline \multicolumn{2}{|l|}{ Weed mat } \\
\hline Planting labor & 3,070 \\
\hline Weed mat ${ }^{z}$ & 593 \\
\hline Installation & 680 \\
\hline $\begin{array}{l}\text { Cutting holes in } \\
\text { weed mat }\end{array}$ & 865 \\
\hline $\begin{array}{l}\text { Appling sawdust mulch } \\
\text { in hole area }\end{array}$ & 593 \\
\hline Sawdust & 334 \\
\hline \multicolumn{2}{|l|}{ Compost + sawdust ${ }^{\mathrm{y}}$} \\
\hline Planting labor & 1,754 \\
\hline Sawdust, raised bed & 2,928 \\
\hline Compost, raised bed & 2,724 \\
\hline Sawdust, flat bed & 2,483 \\
\hline Compost, flat bed & 2,323 \\
\hline \multicolumn{2}{|l|}{ Sawdust $^{\mathrm{x}}$} \\
\hline Planting labor & 1,722 \\
\hline Sawdust, raised bed & 4,497 \\
\hline Sawdust, flat bed & 3,830 \\
\hline
\end{tabular}

zInvestment of $\$ 2965$; 5-year life; 0 residue value. ${ }^{y}$ Custom applied at cost of $\$ 927 /$ ha for sawdust, $\$ 556 /$ ha for compost; the mulched area for raised beds was greater than for flat, requiring more product.

${ }^{\mathrm{x}}$ Custom applied at cost of $\$ 1050 /$ ha sawdust; the mulched area for raised beds was greater than for flat, requiring more product. 
Table 4. Cash costs and returns for organic production of 'Duke' and 'Liberty' blueberry on raised beds. ${ }^{\text {' }}$

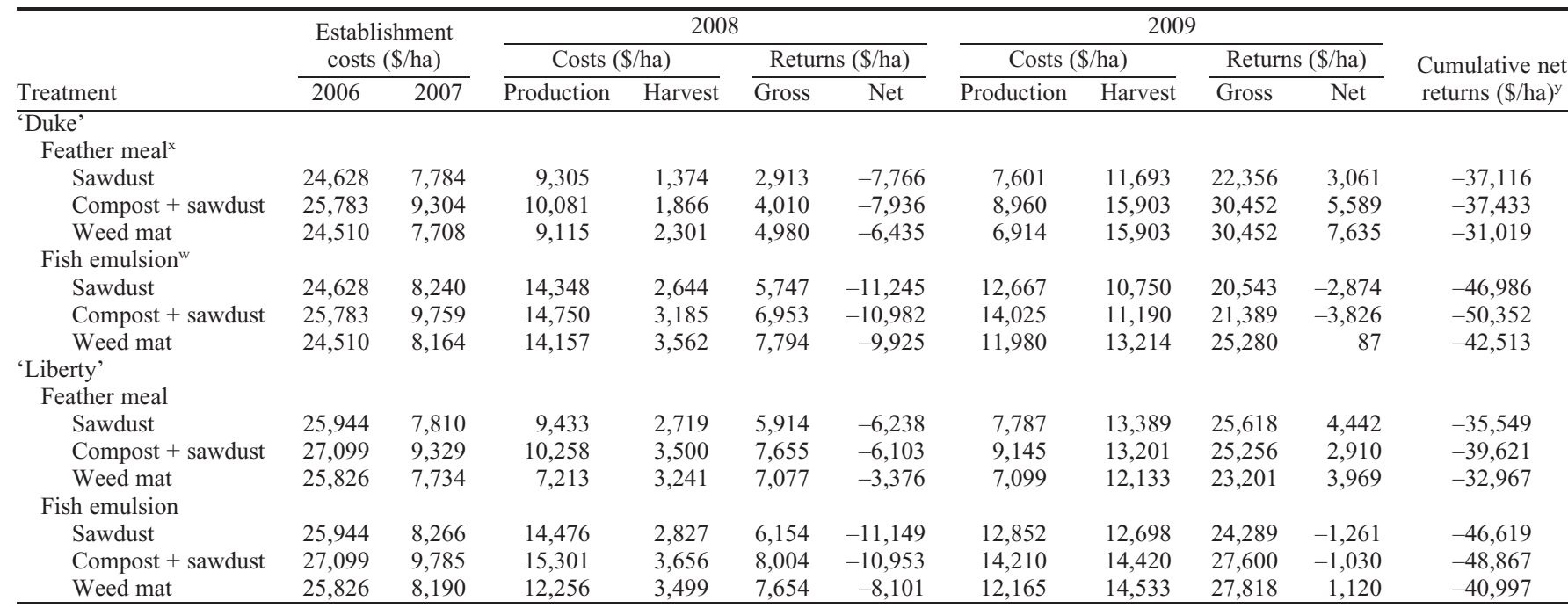

${ }^{7}$ Cost and return data were collected during production and harvest on a per plot basis and extrapolated to per hectare based on plot size.

${ }^{\mathrm{y}}$ From planting in Oct. 2006 to the end of Year 3 in 2009.

${ }^{\mathrm{x}}$ Feather meal was applied at a rate of $57 \mathrm{~kg} \cdot \mathrm{ha}^{-1}$ of nitrogen.

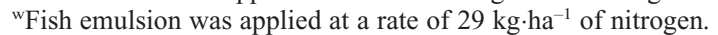

Table 5. Cash costs and returns for organic production of 'Duke' and 'Liberty' blueberry on flat beds. ${ }^{\text {' }}$

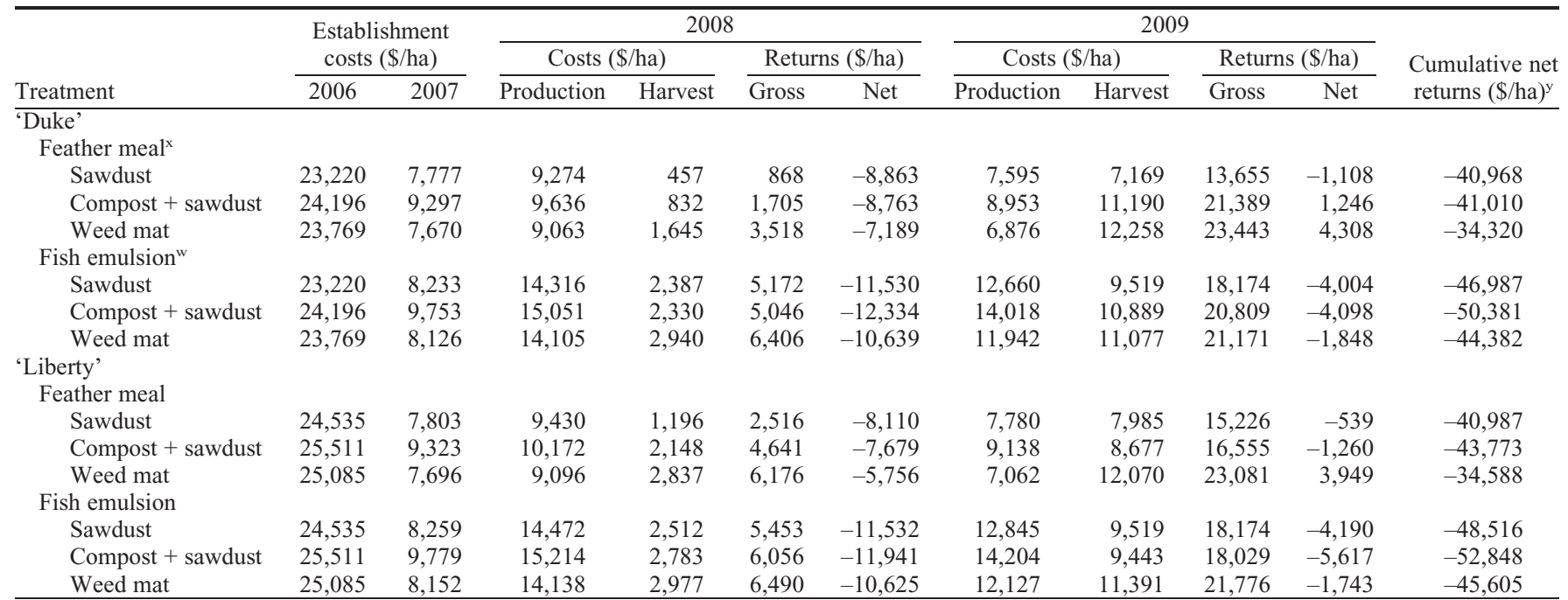

${ }^{2}$ Cost and return data were collected during production and harvest on a per plot basis and extrapolated to per hectare based on plot size.

${ }^{\mathrm{y}}$ From planting in Oct. 2006 to the end of Year 3 in 2009.

${ }^{x}$ Feather meal was applied at a rate of $57 \mathrm{~kg} \cdot \mathrm{ha}^{-1}$ of nitrogen.

wFish emulsion was applied at a rate of $29 \mathrm{~kg} \cdot \mathrm{ha}^{-1}$ of nitrogen.

(Table 2). Plant growth and subsequent fruit production were greater on raised beds than on flat ground likely as a result of improved soil drainage and/or aeration (Larco, 2010; Scherm and Krewer, 2008).

Cultivar. 'Liberty' is a patented cultivar and cost $\$ 0.30$ more per plant or $\$ 1315$ more per hectare than 'Duke' in 2006 (Table 3). 'Duke' and 'Liberty' are popular cultivars for early and mid- to late-season fresh market production, respectively (Strik and Finn, 2008). 'Liberty' required an average of $24 \%$ to $25 \%$ more time or labor cost to prune in 2008 to 2009 (Table 6) but on average produced $5 \%$ higher return than 'Duke' over the 2 years (Table 2), thus increasing net cumulative returns by $\$ 16,441$ and $\$ 16,376 /$ ha for raised and flat beds, respectively (Tables 4 and 5). The fruit from both cultivars sold for $\$ 3.20 / \mathrm{kg}$ in 2008 and $\$ 2.76 / \mathrm{kg}$ in 2009. The was a significant interaction between cultivar and fertilizer applied in both years, because the higher rate of fish emulsion reduced gross returns considerably in 'Duke' but not in 'Liberty' (Table 2).

Fertilizer. The highest gross returns in each bed type, mulch, and cultivar were produced with either a low rate of fish emulsion or a high rate of feather meal (Table 2). Contrasts indicated that the source of fertilizer (feather meal produced higher returns than fish emulsion) was more important than the rate of fertilizer. Fish emulsion cost more than feather meal and was much more expensive to apply considering seven applications were needed compared with two in the feather meal treatment (Table 7). Also, fish emulsion had to be applied with specialized equipment that would not corrode. To reduce application costs, fish emulsion could be applied more cost-effectively by fertigation through a drip irrigation system. In our study, the feather meal fertilizer treatment required additional $\mathrm{N}$, applied using fish emulsion, in 2007, which increased costs by $\$ 573 /$ ha. Additional fish emulsion was not required in subsequent years when the first application of feather meal was done earlier in the season.

Fertilizer source or rate had no significant effect on weed presence or management costs (data not shown). In lowbush blueberry, an overhead-irrigated, non-mulched production system, higher rates of $\mathrm{N}$ fertilization increased weed presence (Smagula et al., 2009). In our study, the fertilizers were applied on top of the 
Table 6. Operation cash costs for organically grown blueberry established on raised and flat beds, Years 1 to 3 (2007 to 2009 )

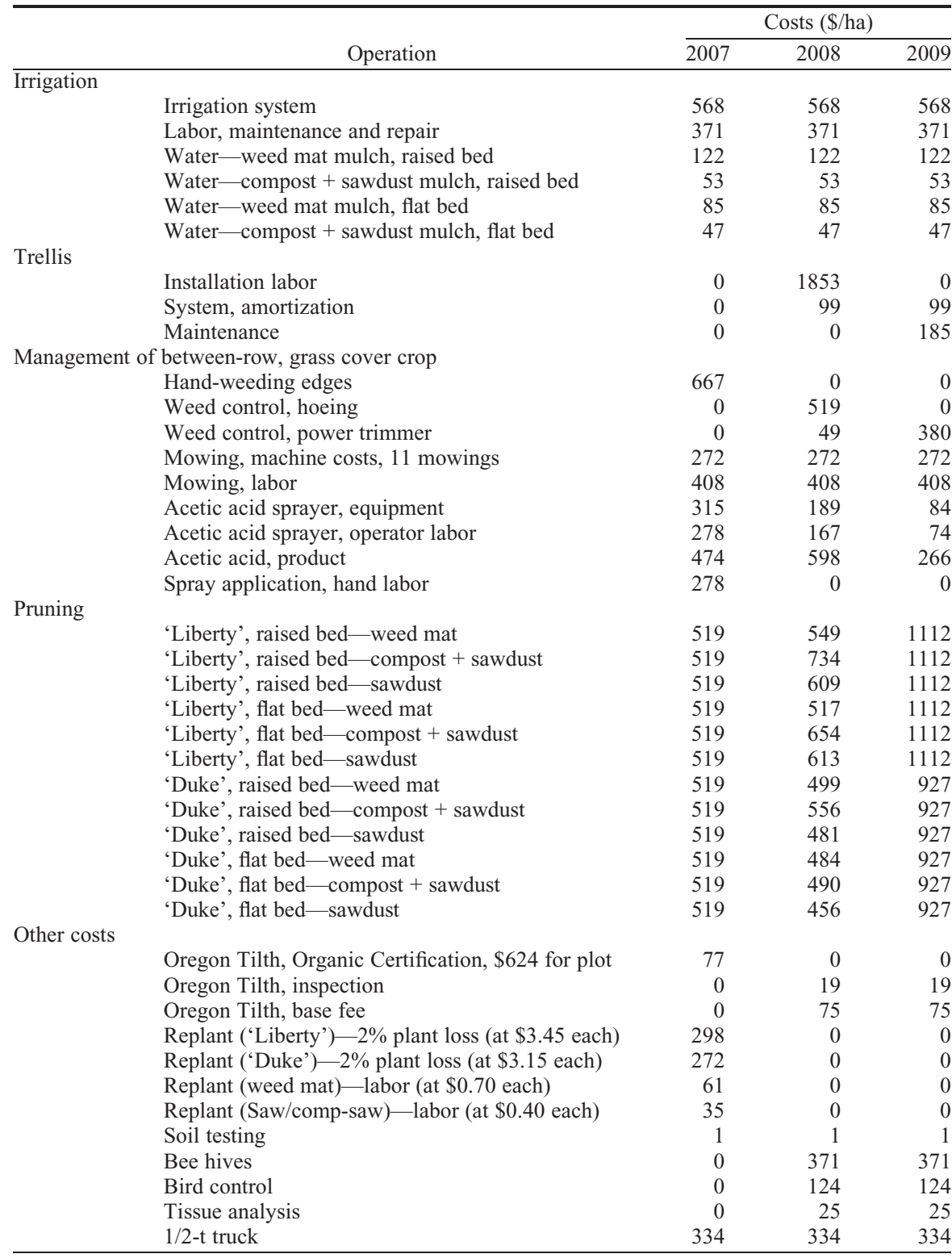

organic mulches and the sawdust around the plant ("planting hole") in the weed mat plots during the establishment years of this study. In a commercial planting, fish emulsion may be applied through the drip irrigation system. It is unlikely that fertilizer placement had an impact on weed presence (Broschat, 2007).

Mulch and weed management. We did not use mechanical methods for in-row weed control in this study. Sciarappa et al. (2008) were able to use a hand-operated rotary cultivator in the row, between blueberry plants, successfully for weed control on flat ground plantings in New Jersey. However, the superior performance of blueberry plants on raised beds in this study, likely as a result of improved soil aeration and drainage (Larco, 2010), led to greater returns on raised beds (Tables 2 and 4). Weed control on raised beds is limited to hand-pulling, mulching, or the use of herbicides to maintain integrity of the bed. Compost + sawdust mulch and weed mat
Table 7. Fertilizer treatment cash costs for organically grown blueberry as affected by mulch type, Years 1 to 3 (2007 to 2009).

\begin{tabular}{|c|c|c|c|}
\hline \multirow[b]{2}{*}{ Fertilizer treatment } & \multicolumn{3}{|c|}{ Cost $(\$ /$ ha $)$} \\
\hline & 2007 & 2008 & 2009 \\
\hline \multicolumn{4}{|l|}{ Fish emulsion $^{z}$} \\
\hline Emulsion, sprayer machine & 711 & 2843 & 2843 \\
\hline Emulsion, sprayer labor & 627 & 2508 & 2508 \\
\hline Emulsion, product & 670 & 670 & 693 \\
\hline \multicolumn{4}{|l|}{ Feather meal $^{\mathrm{y}}$} \\
\hline Application, labor & 448 & 448 & 448 \\
\hline Feather meal, product & 530 & 530 & 530 \\
\hline Emulsion, sprayer machine & 203 & 0 & 0 \\
\hline Emulsion, sprayer labor & 179 & 0 & 0 \\
\hline Emulsion, product & 191 & 0 & 0 \\
\hline
\end{tabular}

Table 8 . Weed management cash costs for organically grown blueberry as affected by mulch type, Years 1 to 3 (2007 to 2009).

\begin{tabular}{lrrr}
\hline & \multicolumn{3}{c}{ Cost (\$/ha) } \\
\cline { 2 - 4 } Operation & 2007 & 2008 & 2009 \\
\hline Weed mat & 102 & 439 & 196 \\
Hand-weeding & & & \\
& & & \\
Compost + sawdust ${ }^{z}$ & 113 & 579 & 1535 \\
$\quad$ Hand-weeding & 0 & 372 & 0 \\
$\quad$ Propane flamer & 517 & 121 & 0 \\
$\quad$ Acetic acid sprayer, & & & \\
$\quad$ equipment & 457 & 107 & 0 \\
$\quad$ Acetic acid sprayer, & & & \\
$\quad$ operator labor & 249 & 130 & 0 \\
$\quad$ Acetic acid, product & 457 & 107 & 0 \\
$\quad$ Spray application, & & & \\
$\quad$ hand labor & 0 & 0 & 428 \\
$\quad$ Weed control, product & 0 & 0 & 348 \\
$\quad$ Spraying, hand labor & 0 & & \\
$\quad$ Sawdust & & & \\
$\quad$ Hand-weeding & 273 & 715 & 953 \\
\hline
\end{tabular}

${ }^{\mathrm{z}}$ Organically approved weed control methods/products were only used in the compost + sawdust treatment.

Planting into organic mulches was less expensive (\$0.40 per plant, labor) than planting through the holes cut into weed mat $(\$ 0.75$ per plant) (Table 3 ).

Weed management varied with the type of mulch used. Only hand-pulling of weeds was used in the sawdust and weed mat treatments, whereas various organically approved methods or products in addition to hand weeding, when necessary, were used in the compost + sawdust treatment. Overall, labor costs were lowest with weed mat, because weeds only emerged in the "planting hole" area around the crown of the plant. Weed control costs for the weed mat were higher in 2008 than in 2007 but lower in 2009 as the plants aged and filled in the hole cut in the weed mat for planting (Table 8). In contrast, labor costs for weed control increased with planting age with sawdust mulch to $\$ 953 /$ ha in 2009.

Weeds were most prevalent in the compost + sawdust treatment (Larco, 2010), increasing weed management costs (Fig. 4). Others have documented better emergence and growth of weed seeds in compost as compared with 


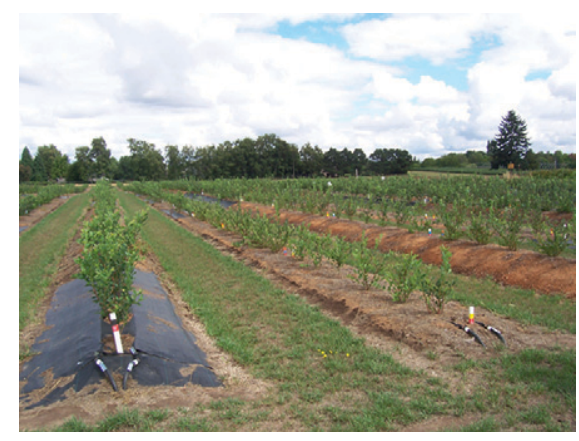

Fig. 1. Organic blueberry production systems planting in the first growing season, 21 Aug. 2007. 'Duke' on raised bed, weed mat mulch, and fertilized with high rate of feather meal on left and 'Duke' on flat ground with sawdust mulch and low rate of feather meal on right foreground.

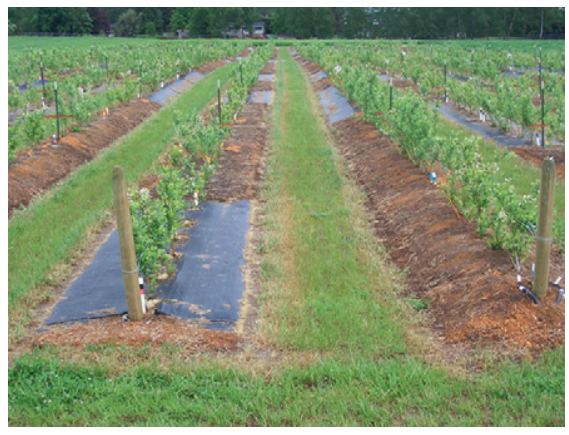

Fig. 2. Organic blueberry production systems planting in the second growing season with trellis installed, 21 May 2008. 'Duke' on raised bed, weed mat mulch, and fertilized with high rate of feather meal on left and 'Duke' on flat ground, compost + sawdust, and fertilized with low rate of fish emulsion on right foreground. Second plots from the front are 'Liberty'

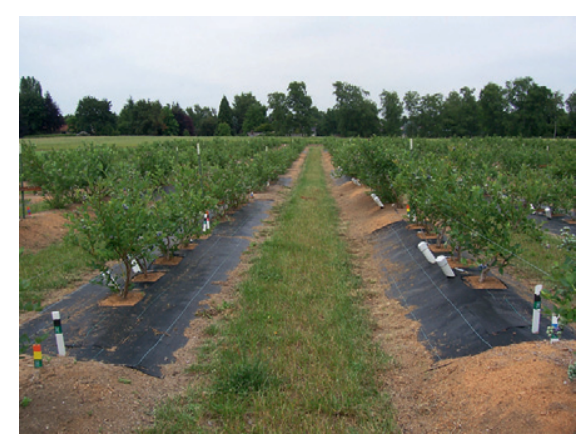

Fig. 3. Organic blueberry production systems planting in the third growing season, 16 June 2009. 'Duke' with weed mat mulch and fertilized with the high rate of fish emulsion grown on flat ground (on left) and raised bed (on right). Note: white tubes in foreground were installed to observe root growth (data not shown).

sawdust or wood chip mulches (Burkhard et al., 2009). In our study, the integrity of the sawdust layer on top of the compost was not well maintained as a result of hand-pulling of weeds bringing compost to the surface and wind erosion of the sawdust layer, especially

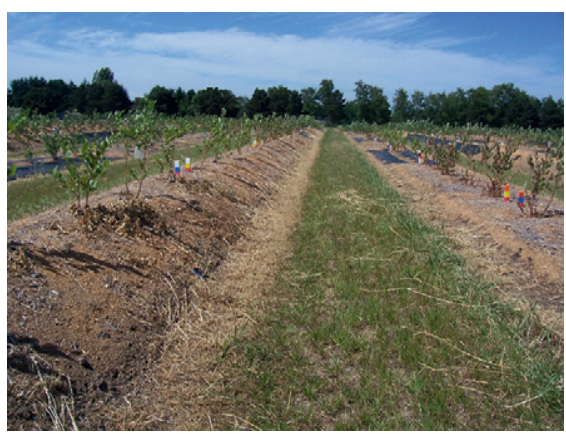

Fig. 4. Symptoms of burn down of broadleaf weeds and edges of grass cover crop in an organic blueberry production systems planting in the first growing season, 20 June 2007. 'Duke' grown with compost + sawdust mulch and fertilized with the high rate of feather meal.

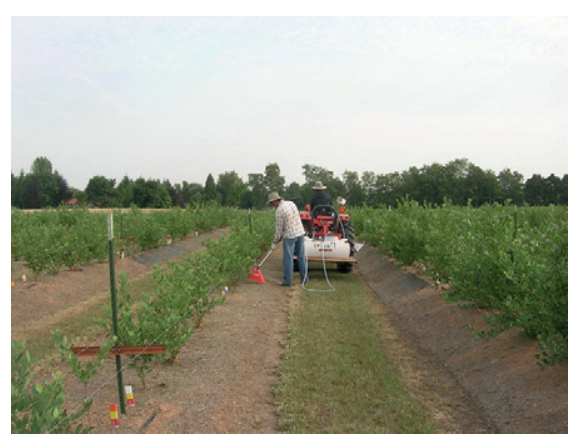

Fig. 5. System used to apply concentrated acetic acid for spot control of weeds in the row, 2008.

on raised beds. Weed seeds likely germinated more readily in the moist, nutrient-rich compost layer.

The methods of weed control varied in their effectiveness. Propane flaming was effective on very small weeds but could not be used in the dry summer months in this dripirrigated field as a result of risk of setting the mulch on fire. We stopped using this control method after 2008. Using a concentrated solution of acetic acid (vinegar) was effective against small weeds, especially broadleaf species, when application was followed by at least 1 or $2 \mathrm{~d}$ of hot, dry weather. Although results seemed to indicate vinegar application effectively controlled larger weeds initially, these often regrew (Figs. 4 and 5). Although the product cost was reasonable for this method of control (e.g., \$249/ha), special equipment had to be constructed and used to prevent corrosion of parts, which added considerable cost and labor for operation (Table 8; Fig. 5). In 2009, small weeds were effectively controlled with post-emergence applications of lemon grass oil, but frequent applications to catch emerging weeds were required and handweeding was still needed to keep the plots free of weeds by the end of the growing season. Our experiences in this study, on the advantages and disadvantages of using organic and inert mulches, flaming, and organic herbicides, agree with the summary provided by Granatstein and Mullinix (2008).
In Year 3 of the study, when weed pressure was greatest, total weed control costs were five- to 12-fold greater in the sawdust mulch (hand-pulling only) and compost + sawdust mulch (various methods of weed control) as compared with the weed mat, respectively (Table 8). Although cumulative costs for establishing cherries were higher when using weed mat than for bare ground production systems, this was quickly offset by higher returns (Yin et al., 2007). Here we found that the much lower weed management costs in addition to amortizing the cost of weed mat over its expected 5-year life offset any added establishment cost by the end of the first growing season when compared with the industry standard sawdust mulch treatment (Tables 4 and 5).

Other maintenance costs. Pruning costs varied with mulch after the first year after planting $(P<0.0001)$ but were unaffected by mulch immediately after planting or following the second year after planting (Table 6).

The irrigation system was installed in Year 1 and irrigation labor and maintenance were similar among treatments. Higher soil water content was measured on flat ground than on raised bed plantings (Larco, 2010), as has been observed by others (Spiers, 1995); raised beds thus required more irrigation to maintain a soil water content within a suitable range for blueberry (Larco, 2010). The cost for pumping the additional irrigation water required on raised beds relative to flat beds was relatively small (Table 6).

Weed mat plots required approximately twice as much irrigation to maintain the same soil water content as plots mulched with compost + sawdust with additional pumping costs of $\$ 69 /$ ha on raised beds (Table 6). Soil water content was less under weed mat than under wood chip mulch in apples [Malus $\times$ sylvestris (L.) Miss. var. domestica (Borkh.) Mansf.; Choi et al., 2011] or compared with bare soil in cherries (Prunus avium L.; Yin et al., 2007), although the impact on irrigation requirement was not addressed in their studies.

A trellis was installed at the beginning of the second year after planting (Fig. 2), as is typical for commercial fields to improve handand machine-harvest efficiency (Strik and Buller, 2005). The trellis also reduced wind damage in 'Liberty' (B.C. Strik, personal observation). The labor to install the trellis in the second growing season was $\$ 1853 /$ ha.

The grass cover crop between the rows was mowed 11 times per growing season, and edges were maintained with a string trimmer, hand-hoeing, or targeted applications of vinegar (Fig. 4). Hand-hoeing to prevent encroachment of the grass cover crop into the planting row was done in 2007 and 2008 at a cost of $\$ 519$ to $667 /$ ha. In all years, vinegar applied to the edges of the cover crop was successfully used but was expensive relative to using a power weed trimmer (Table 6).

Additional production costs included standard replanting costs (estimated $2 \%$ blueberry plant loss in 2008), organic certification and inspection costs (Oregon Tilth, Corvallis, 
OR), annual soil and tissue analysis, equivalent land rent fees, and rental of bee hives and bird control measures during the fruit production years (2008 to 2009; Table 6).

Production costs and returns. The cash costs and returns for 'Duke' and 'Liberty' grown with the three mulch treatments and fertilized with the best performing treatments $\left(29 \mathrm{~kg} \cdot \mathrm{ha}^{-1}\right.$ of $\mathrm{N}$ as fish emulsion and $57 \mathrm{~kg} \cdot \mathrm{ha}^{-1}$ of $\mathrm{N}$ as feather meal; Table 2) on raised or flat beds are shown in Tables 4 and 5, respectively. Total establishment costs for the first two growing seasons when there was no fruit harvest are presented. Harvest costs in 2008 and 2009 included picking labor, loading and hauling, picking buckets, and use of a bin trailer. Gross returns reflect fruit sales from harvested yield.

Cumulative net returns ranged from -\$32,967 ('Duke' grown on weed mat, fertilized with feather meal) to $-\$ 50,352 /$ ha ('Duke' grown with compost + sawdust, fertilized with fish emulsion) when grown on raised beds (Table 4). On flat plantings, cumulative net returns ranged from $-\$ 34,320$ ('Duke' grown on weed mat, fertilized with feather meal) to $-\$ 52,848 /$ ha ('Liberty' grown with compost + sawdust, fertilized with fish emulsion) (Table 5). It is typical in blueberry production to have negative cumulative net returns at this stage of planting establishment (Julian et al., 2011a, 2011b).

Plantings established on raised beds had a greater cumulative net return than those grown on flat beds. Although 'Duke' had lower establishment and pruning costs, 'Liberty' produced higher yield, which led to higher net returns in all treatment combinations except feather meal with either weed mat or compost + sawdust mulch (Table 5). When using raised beds, the highest net cumulative returns in this study were found in plots mulched with weed mat and the lowest in those mulched with compost + sawdust, attributable mainly to higher production costs for weed management.

\section{Conclusions}

In this young planting, the highest yielding treatments for 'Duke' and 'Liberty' grown on raised beds were those fertilized with the low rate of fish emulsion and mulched with either weed mat or compost + sawdust. However, the net cumulative returns for these treatments differed considerably with a potential savings of $\approx \$ 7800 /$ ha when choosing weed mat mulch over compost + sawdust mulch. Although the cumulative returns (2008 to 2009) were higher for plants fertilized with the low rate of fish emulsion than with the high rate of feather meal, there was less difference between these treatments in 2009, especially in 'Liberty'. In our study, where fertilizers were applied by hand to the young plants, use of feather meal compared with fish emulsion in weed mat plantings saved $\$ 8,030$ to $\$ 11,494 /$ ha in 'Liberty' and 'Duke', respectively. It is likely that some of our recorded costs for treatment plots could be reduced when practices are done on larger commercial plantings. For example, in commercial plantings, "zippered" weed mat (overlapping sections pinned to remain in place) may be used allowing granular fertilizer products such as feather meal to be applied using a spreader and fish emulsion could be applied through drip irrigation systems reducing costs (Julian et al., 2011b). Although the long-term effect of these treatments on economic returns is not yet known, it is clear that choice of production system has significant effects on returns in organic blueberry production systems in the Pacific Northwest.

\section{Literature Cited}

Bañados, M.P., B.C. Strik, D.R. Bryla, and T.L. Righetti. 2012. Response of highbush blueberry to nitrogen fertilizer during field establishmentI. Accumulation and allocation of fertilizer nitrogen and biomass. HortScience 47:648-655.

Broschat, T.K. 2007. Effects of mulch type and fertilizer placement on weed growth and soil $\mathrm{pH}$ and nutrient content. HortTechnology 17:174-177.

Burkhard, N., D. Lynch, D. Percival, and M. Sharifi. 2009. Organic mulch impact on vegetation dynamics and productivity of highbush blueberry under organic production. HortScience 44:688-696.

Chandler, R.B. and E.C. Mason. 1942. The effect of mulches on soil moisture, soil temperature, and growth of blueberry plants. Proc. Amer. Soc. Hort. Sci. 40:335-337.

Choi, H.-S., C.R. Rom, and M. Gu. 2011. Plant performance, and seasonal soil and foliar nutrient variations in an organic apple orchard under four ground cover management systems. J. Amer. Pom. Soc. 65:130-146.

Clark, J. 1991. Rabbiteye and southern highbush blueberry response to sawdust mulch. Arkansas Farm Res. (Jan.-Feb):3.

Clark, J.R. and J.N. Moore. 1991. Southern highbush blueberry response to mulch. HortTechnology 1:52-54.

Eck, P. 1988. Blueberry science. Rutgers Univ. Press, New Brunswick, NJ. p. 135-169.

Fausey, J.C. 2003. Controlling liverwort and moss now and in the future. HortTechnology 13: $35-38$.

Gale, E.S., D.M. Sullivan, D. Hemphill, C.G. Cogger, A.I. Bary, and E.A. Myhre. 2006. Estimating plant-available nitrogen release from manures, composts, and specialty products. J. Environ. Qual. 35:2321-2332.

Granatstein, D. and K. Mullinix. 2008. Mulching options for northwest organic and conventional orchards. HortScience 43:45-50.

Griggs, W.H. and H.A. Rollins. 1947. The effect of planting treatment and soil management systems on the production of cultivated blueberries. Proc. Amer. Soc. Hort. Sci. 49:213-218.

Hanson, E.J. 2006. Nitrogen nutrition of highbush blueberry. Acta Hort. 715:347-351.

Hart, J., B. Strik, L. White, and W. Yang. 2006. Nutrient management for blueberries in Oregon. Oregon State Univ. Ext. Ser. Pub., EM 8918.

Julian, J., B. Strik, and W. Yang. 2011a. Blueberry economics: The costs of establishing and producing blueberries in the Willamette Valley, Oregon. Oregon State Univ. Pub. AEB 0022. $<\mathrm{http}$ ///arec.oregonstate.edu/oaeb/files/pdf/ AEB0022.pdf>.

Julian, J., B. Strik, E. Pond, and W. Yang. 2011b. Blueberry economics: The costs of establishing and producing organic blueberries in the Willamette Valley, Oregon. Oregon State
Univ. Pub. AEB 0023. <http://arec.oregonstate. edu/oaeb/files/pdf/AEB0023.pdf>.

Krewer, G., M. Tertuliano, P. Andersen, O. Liburd, G. Fonsah, H. Serri, and B. Mullinix. 2009. Effect of mulches on the establishment of organically grown blueberries in Georgia. Acta Hort. 810:483-488.

Larco, H.O. 2010. Effect of planting method, weed management, and fertilizer on plant growth and yield of newly established organic highbush blueberries. MS thesis, Oregon State Univ., Corvallis, OR. $<\mathrm{http} / /$ ir.library.oregonstate.edu/ xmlui/handle/1957/18065>.

Lareau, M. 1989. Growth and productivity of highbush blueberries as affected by soil amendments, nitrogen fertilization and irrigation. Acta Hort. 241:126-131.

Moore, J.N. 1979. Highbush blueberry culture in the upper south. 4th Natl. Blueberry Res. Workers Conf. 4:84-86.

Neilsen, G.H., E.J. Houge, T. Forge, and D. Neilsen. 2003. Mulches and biosolids affect vigor, yield, and leaf nutrition of fertigated high density apple. HortScience 38:41-45.

Pritts, M.P. and J.F. Hancock. 1992. Highbush blueberry production guide. NRAES-55, Ithaca, NY.

Runham, S.R., S.J. Town, and J.C. Fitzpatrick. 2000. Evaluation over four seasons of a paper mulch used for weed control in vegetables. Acta Hort. 513:193-201.

Scherm, H. and G. Krewer. 2008. Disease management in organic rabbiteye blueberries. Intl. J. Fruit Sci. 8:1-2.

Sciarappa, W., S. Polavarapu, J. Barry, P. Oudemans, M. Ehlenfeldt, G. Pavlis, D. Polk, and R. Holdcraft. 2008. Developing an organic production system for highbush blueberry. HortScience 43:51-57.

Sikora, L.J. and R.A.K. Szmidt. 2001. Nitrogen sources, mineralization rates, and nitrogen nutrition benefits to plants from composts, p. 287-305. In: Stofella, P.J. and B.A. Kahn (eds.). Compost utilization in horticultural cropping systems. CRC Press, Boca Raton, FL.

Smagula, J.M., D.E. Yaborough, F. Drummond, and S. Annis. 2009. Organic production of wild blueberries. II. Fertility and weed management. Acta Hort. 810:673-684.

Spiers, J.M. 1995. Substrate temperatures influence root and shoot growth of southern highbush and rabbiteye blueberries. HortScience 30:1029-1030.

Strik, B. 2007. Horticultural practices of growing highbush blueberries in the ever-expanding U.S. and global scene. J. Amer. Pomol. Soc. 61:148-150.

Strik, B. and G. Buller. 2005. The impact of early cropping on subsequent growth and yield of highbush blueberry in the establishment years at two planting densities is cultivar dependent. HortScience 40:1998-2001.

Strik, B., C. Brun, M. Ahmedullah, A. Antonelli, L. Askam, D. Barney, P. Bristow, G. Fisher, J. Hart, D. Havens, R. Ingham, D. Haufman, R. Penhallegon, J. Psheidt, B. Scheer, C. Shanks, and R. Williams. 1993. Highbush blueberry production. Oregon State Univ. Pacific Northwest Ext. Pub. 215.

Strik, B.C. and C.E. Finn. 2008. Blueberry cultivars for Oregon. Oregon State Univ. Ext. Serv. Pub. EC 1308, Corvallis, OR.

Sullivan, D.M., A.I. Bary, T.J. Nartea, E.A. Myrhe, C.G. Cogger, and S.C. Fransen. 2003. Nitrogen availability seven years after a high-rate food waste compost application. Compost Sci. Util. 11:265-275. 
Takele, E., B. Faber, M. Gaskell, G. Nigatu, and I. Sharabeen. 2008. Sample costs to establish and produce organic blueberries in the coastal region of Southern California, San Luis Obispo, Santa Barbara, and Ventura Counties, 2007. Univ. Cal. Coop. Ext., BR-SC-07-O.

USDA-AMS-NOP. 2011. Program handbook: Guidance and instructions for accredited certifying agents \& certified operations. Winter edition.

Webber, C.L., M.A. Harris, J.W. Sherefler, M. Durnova, and C.A. Christopher. 2005. Vinegar as an organic burn-down herbicide, p. 168-172. Proc. 24th Annual Oklahoma and Arkansas Hort. Industry Show. Fort Smith, Ark.

White, L.D. 2006. The effect of pre-plant incorporation with sawdust, sawdust mulch, and nitrogen fertilizer. MS thesis, Oregon State Univ., Corvallis, OR. <http://hdl.handle.net/1957/1363>.

Williamson, J., G. Krewer, G. Pavlis, and C.M. Mainland. 2006. Blueberry soil management, nutrition and irrigation. In: Childers, N.F. and P.M. Lyrene (eds.). Blueberries for growers, gardeners and promoters. E.O., Gainesville, FL.

Yin, X., C.F. Seavert, J. Turner, R. Núñez-Elisea, and H. Cahn. 2007. Effects of polypropylene groundcover on soil nutrient availability, sweet cherry nutrition, and cash cost and returns. HortScience 42:147-151.

Young, S.L. 2004. Natural product herbicides for control of annual vegetation along roadsides. Weed Technol. 18:580-587. 